\title{
Analysis of Students' Learning Difficulties in Learning Mathematics at Elementary Schools
}

\author{
Yulita1, Siti Quratul Ain² \\ DOI: $10.35445 /$ alishlah.v13i2. 745
}

Article Info

Keywords:

Learning Difficulties;

Mathematics;

Elementary School

Students

Kata kunci:

Kesulitan Belajar;

Matematika;

Siswa Sekolah Dasar

\begin{abstract}
This study aims to know the difficulty in learning mathematics experienced by fourth-grade students of SDN 169 Pekanbaru regarding understanding concepts. This study uses descriptive qualitative research with primary data sources from teachers and students of class IV SDN 169 Pekanbaru and secondary data sources obtained from documents and archives supporting learning in class IV to analyze student learning difficulties in mathematics in class IV SDN 169 Pekanbaru. The data collection techniques were obtained through interviews, observation and documentation techniques. To obtain the validity of objective data in qualitative research, the researcher will use source triangulation and technical triangulation. This study uses data analysis techniques Miles and Huberman, namely data collection, data reduction, data presentation and data inference. The results showed students' difficulties in using concepts, difficulties in using principles, and difficulties solving verbal problems. The factors that cause students to experience learning difficulties in learning mathematics in class IV SDN 169 Pekanbaru include internal and external factors. The factors that come from within students (internal) include physical factors, psychological factors (intelligence, attention, interest, talent, motivation), and fatigue. In contrast, the factors that come from outside the student (external) include family factors, school factors (learning methods, learning tools, teaching methods), and community factors.
\end{abstract}

\begin{abstract}
Abstrak
Tujuan penelitian ini adalah untuk mengetahui kesulitan belajar matematika yang dialami oleh siswa kelas IV SDN 169 Pekanbaru mengenai pemahaman konsep. Penelitian ini menggunakan jenis penelitian kualitatif deskriptif dengan sumber data primer diperoleh dari guru dan siswa kelas IV SDN 169 Pekanbaru dan sumber data sekunder diperoleh dari dokumen dan arsip penunjang pembelajaran pada kelas IV dalam analisis kesulitan belajar siswa dalam pembelajaran matematika kelas IV SDN 169 Pekanbaru. Adapun teknik pengumpulan data diperoleh melalui teknik wawancara, observasi dan dokumentasi. Untuk memperoleh keabsahan data yang objektif dalam penelitian kualitatif, maka peneliti akan menggunakan triangulasi triangulasi sumber dan triangulasi teknik. Penelitian ini menggunakan teknik analisis data Miles dan Huberman yaitu data collection, reduksi data, penyajian data dan penyimpulan data. Hasil penelitian menunjukkan kesulitan siswa dalam penggunaan konsep, kesulitan siswa dalam penggunaan prinsip, dan kesulitan siswa dalam menyelesaikan masalah verbal. Faktor-faktor yang menyebabkan
\end{abstract}

\footnotetext{
${ }^{1}$ Universitas Islam Riau, Pekanbaru, Indonesia

Email: yulitanasution21@gmail.com

${ }^{2}$ Universitas Islam Riua, Peknabaru, Indonesia

Email: quratulain@edu.uir.ac.id
} 
siswa mengalami kesulitan belajar dalam pembelajaran matematika di kelas IV SDN 169 Pekanbaru diantaranya faktor internal dan faktor eksternal. Faktor yang berasal dari dalam diri siswa (internal) diantaranya berupa faktor jasmaniah, faktor Psikologis (inteligensi, perhatian, minat, bakat, motivasi), dan faktor kelelahan. Sedangkan Faktor yang berasal dari luar diri siswa (eksternal) diantaranya berupa faktor keluarga, faktor sekolah (metode belajar, alat pelajaran, metode mengajar), dan faktor masyarakat.

\section{INTRODUCTION}

The essence of education is the learning of students. According to (Djumali et al., 2014), "education is to prepare humans to solve the problems of life in the present and the future." Education is an effort to help students physically and mentally from their innate nature towards human and better civilization (Sujana., 2019). This naturally can be obtained through the learning process. Learning is the process of a student experiencing a change from one condition to another. The other conditions are well planned and controlled. To arrive at the desired condition, efforts must take various ways, pass through various conditions, and follow several principles that become rules in learning.

Learning is the process of a person changing his or her behavior as a result of his or her efforts in engaging with his or her surroundings. One of the subjects taught in primary school is mathematics. When teaching mathematics to his students, a teacher should be familiar with and understand the subject matter. According to Hasan (2015), mathematics is the foundation of science and may be used to solve various problems in everyday life, but students typically struggle to master it. Several stakeholders, including teachers, school surroundings, and student guardians, must pay more attention to this. Mathematics is the most challenging topic for students among the numerous disciplines of study offered in schools. The fact that mathematics is regarded as a complex subject for students to comprehend is backed up by the large number of students who dislike it, as well as the 2014 OECD report that stated that Indonesia was ranked 64th out of 65 countries in 2012, with a score of 375 , and that 75.7 percent of Indonesian students have poor performance (Nur \& Palobo, 2018). Students' hatred of studying, particularly mathematics, appears to impact insufficient passion and motivation to learn, inability to understand the subject matter, avoiding subjects, and ignoring instructor assignments, resulting in worse learning scores and student accomplishment (Mufarizuddin, 2018).

According to Mulyadi (2010), difficulties are generally conditions marked by obstacles to someone achieving goals. Thus, hard work is required to overcome them. Learning difficulties are obstacles in the learning process to achieve learning outcomes. Students often have difficulty learning mathematics because the abstract mathematics material makes it difficult to understand mathematics learning.

Based on the results of interviews conducted on February 8, 2021, at SDN 169 Pekanbaru. The researchers obtained information from the fourth-grade teacher who stated that the students' lack of interest in learning mathematics was because students already assumed that mathematics was a complex subject, students had difficulty working on story problems. Students were confused by the many formulas in learning mathematics. Furthermore, during the learning process of mathematics, the teacher is less in using the media. Thus, students are less enthusiastic in learning, and it is not easy to understand the teacher's explanation.

Difficulties in learning mathematics are seen when students cannot learn correctly, achieve learning goals, and achieve the target learning objectives well. This statement is in line with the analysis of learning difficulties by Murzani (2018) with the results of research that many students have difficulty in learning mathematics, difficulties in learning mathematics experienced by students are difficulties in understanding concepts, difficulties in calculations, difficulties in understanding problem-solving. Internal factors include body and mental conditions, low intelligence, inattention, study habits, low interest in learning, low learning motivation, and 
external factors such as lack of parental attention, student-parent relationships, less conducive home environment, and living environment conditions all contribute to learning difficulties.

Based on a previous study conducted by Amalia and Unaenah (2018), students have difficulty with numeracy skills. Many students make mistakes in performing calculations on two subtraction operations on fractions, and students making mistakes in calculating the difference in fractional values. Meanwhile, for students who experience difficulties in the problem-solving section, students mostly make mistakes in solving the final problem. Another previous study also found that the difficulties in learning mathematics experienced by students lie in facts, concepts, skills, and principles (Waskitoningtyas, 2016). Students' difficulty in facts is $14.4 \%$, categorized as very low. In this case, students who cannot capture the facts given by the questions, both information about what is known and what is asked in the questions, have difficulty-errors in the use of symbols which are facts in mathematics-for example, writing down the timestamp incorrectly and miswriting the numeric notation. The similarity between the research conducted and the research conducted by Nurul and Rahayu both examined conceptual understanding. The difference was that this study also discussed learning mathematics (factors that make it difficult for students to learn to understand a concept). In both these studies, it can be concluded that students have learning difficulties understanding the problem and how to solve the problem. Therefore, it needs to be studied more deeply related to the factors that influence these problems.

\section{METHOD}

This study employed a descriptive qualitative method which was conducted at SDN 169 Pekanbaru. Merpati Raya Street No.3 Gerilya Nusantara housing complex, Maharatu, Marpoyan Damai Subdistrict, Pekanbaru. The study was carried out in April 2021 for the 2020/2021 Academic Year. Data collection techniques employed in this study include interviews, observation, and documentation. To obtain the validity of objective data in qualitative research, the researchers utilized triangulation. Triangulation is a data collection technique that combines data collection techniques, namely Observation, Interview, Documentation from various existing data sources. This study also employed data analysis techniques called Miles and Huberman. Activities in this data analysis were: Data collection, data reduction, data presentation (data display), and Conclusion Drawing / Verification.

\section{FINDINGS AND DISCUSSION}

The difficulties experienced by students of class IVB SDN 169 in learning mathematics three are students' difficulties in using concepts, students' difficulties in using principles, and difficulties in solving verbal problems. This is also in line with research that has been carried out by (Yusmin, 2016) which concluded that learning difficulties in mathematics are classified into three types, including (1) student difficulties in using concepts, (2) student difficulties in using principles, (3) students' difficulties in solving verbal problems.

\section{Students' difficulties in using concepts}

Based on the results of interviews with the IVB class teacher, Mrs. NS, on June 4, 2021, she said that students had difficulties in learning mathematics. From her teaching experience, she said that the difficulties often experienced by students in learning mathematics were about understanding each learning concept which was very difficult to understand. Even though it was explained repeatedly, there were still many students who did not understand and students also found it difficult to learn using formulas because there were still many who were confused about how to enter formulas so that there were still students who only answered questions given. Moreover, students were also very difficult to understand questions in the form of a story because students do not like to read and also do not know what is being asked and what is known from the questions in the form of the story so that it makes them confused and difficult to understand the lesson. 
This difficulty is shown when students cannot work on questions about some of the material that the teacher is asked to do. There are still students who do not answer the questions because they do not understand the concept of the question. These conditions are found in a study conducted by Andri (2020) on the analysis of learning difficulties in mathematics with the conclusion that students' difficulties in the material are due to a lack of understanding of students in understanding concepts and often misusing formulas in solving problems. Meanwhile, according to Melisari (2020), the root causes of the problem of lack of understanding of students' mathematical concepts includes students do not think about the concepts that have been studied so that the concepts learned do not last long, students are reluctant to understand practice questions first in working on problems and assume that the problem is difficult to do, students find it difficult to apply the material in everyday life. Murzani (2018) confirmed this, which states that understanding the concept is further learning from concept planting. Therefore, to be able to understand the concept, it must begin with planting the concept. The ultimate goal of learning mathematics in elementary school (SD) is to enable students to use various mathematical concepts in everyday life. In this study, the difficulties in understanding the concepts experienced by students were difficulties in the concepts of several subject matter. Concept understanding refers to students' basic understanding of mathematical concepts. Indicators of difficulty in understanding mathematical concepts are difficulties in determining the formula to solve a problem and students in using the formula not under the prerequisite conditions for applying the formula or not writing the formula. The mistakes made by students in solving these problems indicate that students still do not understand the basic concepts expected from the learning, so that they have learning difficulties. This is reinforced by the opinion made by Widyasari (2015), which states that "A person or group of students who have difficulty in achieving the expected level of completeness can be caused because there are basic concepts that have not been mastered." Thus, it can be said that it is true that students have difficulty in learning mathematics on various materials studied in terms of understanding mathematical concepts.

Understanding concepts in mathematics is the first ability that is expected to be achieved in mathematics learning objectives. Fauzi, Irfan, and Andika (2020) suggest that it is essential to understand the concept of being mastered by students in dealing with variations in the form of mathematics problems they face. The importance of understanding concepts is the basis in obtaining the expected learning outcomes. The use of concepts in mathematics is related to understanding and distinguishing words, symbols, and signs. Based on interviews with the researchers found several problems regarding students' understanding of concepts. The results of the interviews showed that students did not master the understanding of the concept. However, mastery of concepts needs to be owned by students to understand the material being taught. This is in line with a statement made by Unaenah (2019) in which an understanding and mastery of a material or concept is a prerequisite for mastering the next material.

Based on the findings of the observations, it can be seen that many students still believe that mathematics is a boring subject with difficult lessons. It can also be seen that when students bring their worksheets to school, there are still many students who do not complete all of the questions that the teacher has asked them to complete at home and that not all students scored above. As a result, some of the questions they did not understand were left unanswered, or the responses were incomplete. Students have conceptual difficulties because they have difficulty connecting complex problems, according to a previous study conducted by Yeo (2009) on Secondary 2 Students' Difficulties in Solving Non-Routine Problems. Students also have difficulty understanding appropriate mathematical concepts and applying them to problem-solving strategies.

Based on the study of documents, teachers at SDN 169 Pekanbaru have lesson plans, syllabus, and worksheets collected twice a week and delivered to the school. The lesson plan used by the teacher is the distance learning lesson plan (online method) due to the current covid situation. The syllabus used is under the teacher's lesson plans. In the student worksheet, the teacher informs students about the work on assignments collected twice a week delivered through the WhatsApp 
Group. The change from offline learning to online learning might cause students' understanding of a concept to become a problem, especially in mathematics. This is in line with Wiryanto's (2020) opinion that the negative impact was also felt by various elements, including teachers, students, and parents from the COVID-19 pandemic. Negative impacts are felt, such as teachers and students not providing feedback quickly, children's understanding of a material is not comprehensive enough.

\section{Students' difficulties in using the principle}

Based on the results of an interview with a class IV B teacher, Mrs. NS, on June 4, 2021, she said that students had difficulties in learning mathematics. The difficulties experienced by students were about understanding each principle of learning mathematics. It was challenging for students to understand. Even though it was explained repeatedly, but there are still many students who do not understand. Because students do not understand the concept of learning, they have difficulty in the next step of learning. The use of principles in learning mathematics is an essential aspect for students to master because this aspect is closely related to the way students solve a problem. According to Fauzi, Irfan, and Andika (2020), using principles in learning mathematics includes discovery activities, looking for relevant factors, and concluding a meaning to apply something they find. In addition, the difficulties found related to the use of the principle are the difficulty of students in interpreting the form of the questions that have been presented. Students also feel confused with the form of the questions. Meanwhile, Yuniawardani (2018) said that students must first understand mathematical concepts to understand the principles if they want to master mathematics. Students' ability to solve problems can be seen from the learning outcomes.

Based on the results of observations made, it can be seen that there are still many students who think that mathematics is a boring subject and the lessons are very difficult. In this study, it can be seen that when students collect students' worksheets to school that there are still many students who do not do all the questions asked by the teacher to do it at home. Not all students scored above the Minimum Mastery Criteria in working on these questions because they did not understand the questions given, so the parts they did not understand were not answered, or the answers were empty.

Based on the study of documents, teachers at SDN 169 Pekanbaru have lesson plans, syllabus, and worksheets collected twice a week and delivered to the school. The lesson plan used by the teacher is the distance learning lesson plan (online method) due to the current covid situation. The syllabus used is under the teacher's lesson plans. In the students' worksheet, the teacher informs students about the work on assignments collected twice a week, delivered through the WhatsApp group. Based on the results of interviews with teachers, observations, and documentation, it is known that students have difficulty in using mathematical principles from various materials. Difficulties in understanding and applying the principles occur because students do not understand the basic mathematics concepts.

\section{Students' difficulty in solving verbal problems}

According to the results of interviews with Mrs. NS, the IVB class teacher, on June 4, 2021, pupils found it difficult to work on story problems. Students disliked reading because it was difficult for them to answer questions in the form of stories. Students who enjoy reading, on the other hand, will understand perfectly. It is true that when a question is presented in the form of a story, many pupils will walk around and ignore the teacher's explanation of the lesson in the form of a story. They dislike the lecture and, despite numerous explanations, find it impossible to comprehend the significance of the question. Understanding diverse particular terminology is intimately tied to linguistic problems. As a result, students must have the capacity to understand numerous terminology in order to solve various difficulties. The challenges of the students were discovered to be related to verbal issues in this study. According to Fauzi, Irfan, and Andika (2020), these issues are frequently caused by students' incapacity to apply mathematical concepts and principles. According to Dwidarti et al., (2019), story questions are provided in the form of short stories. The narrative told could be about everyday life or other issues. Math story problems are math problems 
that are written in the style of a tale and must be translated into mathematical words or equations. Many pupils struggle and make mistakes when addressing story issues. Students struggle with story issues because they ignore reading and understanding each sentence, what is known in the question and what is asked, and how to solve the problem appropriately. Difficulty learning mathematics is a roadblock that students have when learning mathematics, specifically when solving story problems. This is in line with Utari, Dian Rizky's (2019) argument, which claims that students' difficulties in answering problems are due to a lack of understanding of the meaning of story questions. Furthermore, according to Abrar (2018), this issue is frequently caused by students' incapacity to apply mathematical concepts and principles. The problem is that students cannot comprehend the context of the questions offered; students are still having trouble applying formulas, grasping theorems, and, most importantly, understanding the problems in a problem set (Sholihah, S. Z., \& Afriansyah., 2017).

Problem-solving is one of the skills that students must master after learning mathematics. According to Robert L. Solso (Siti Mawaddah, 2015). Problem-solving is a thought that is directed directly to find a solution or a way out for a specific problem. Meanwhile, Siwono (2008) argues that problem-solving is a process or individual effort to respond or overcome obstacles or obstacles when an answer or answer method is unclear. Thus, problem-solving is an individual's thought process in a directed manner to determine what must be done in overcoming a problem. Kesumawati (Chotimah, 2014) states that mathematical problem-solving ability is the ability to identify the elements that are known, asked, and the adequacy of the elements needed, able to create or compose mathematical models, can choose and develop solving strategies, be able to explain and check the correctness of the answers obtained. This ability is needed by students related to the needs of students to solve the problems they face in everyday life and develop themselves. According to Polya (Sulaiman, 2016), indicators of problem-solving ability include understanding the problem, prepare a settlement plan, completing the settlement plan, and looking back at the honest answer.

The analysis of the difficulty of solving story problems indicates that students cannot interpret sentences in story problems and work on story problems that are not under the steps of solving mathematical problems. Thus, students cannot solve problems correctly. Children who have difficulty learning mathematics have a lack of understanding of mathematical language. This lack of understanding causes students to have difficulty making meaningful mathematical relationships, as happens in solving problems presented in the form of stories. The development of indicators of problem-solving is indicated by students not continuing their work in solving problems. The analysis of the difficulty of solving problems in story problems indicates that students cannot interpret sentences in story questions and do not determine the correct problem-solving steps causing them to fail to solve the problem correctly. Students did not work on the questions in the form of a story based on the material in the questions, and they did not work on the questions in the correct steps, for example. Andri (2020) claims that students who struggle with mathematics lack a grasp of mathematical language. Students struggle to make significant mathematical connections due to their lack of comprehension, as was the case when attempting to solve difficulties offered in the form of stories. The argument that the type of difficulty in learning mathematics experienced by pupils is the difficulty of solving difficulties in story problems is found to be true based on theory and research findings. The results of a study conducted by Kereh, C. T., Sabadar, J., and Tjiang support the causes of these challenges (2013). Students' mathematical difficulties in problem-solving abilities were studied, including incomplete mastery of number facts, difficulty performing calculations, difficulty transferring knowledge, difficulty making relationships, lack of understanding of mathematical language, difficulty understanding visual and spatial aspects, and difficulties perceiving (spatial).

\section{CONCLUSION}

The learning difficulties experienced by students in mathematics in class IV SDN 169 Pekanbaru are: Students' difficulties in using concepts, students' difficulties in using principles, and students' difficulties in solving verbal problems. In addition, the factors that cause students to 
experience learning difficulties in learning mathematics in class IV SDN 169 Pekanbaru include internal and external factors. Factors that come from within students (internal) include physical factors, psychological factors (intelligence, attention, interest, talent, motivation), and fatigue. Meanwhile, the factors that come from outside the students (external) include family factors, school factors (learning methods, learning tools, teaching methods), and community factors. The improvement efforts used by teachers in overcoming students' learning difficulties in grade IV mathematics subjects at SDN 169 Pekanbaru include: providing remedial teaching, providing material repetition activities (enrichment), providing learning motivation to students, improving attitudes and good study habits, Using concrete learning media, increasing practice questions. Teachers need to provide more practice questions to students who have difficulty learning mathematics. With more practice, students will understand better and cooperate with parents since parents have an important role in motivating students. It is suggested that the teachers should be teachers to reaffirm the learning of concepts and principles that tend to be difficult for students to master. Likewise, teachers are encouraged to apply some appropriate methods that students can use to make it easier to implement a step or strategy or procedure in solving mathematical problems and minimizing or overcoming the difficulties experienced by students. Future researchers are suggested to be able to conduct further research to find the causal factors and solutions for learning difficulties in mathematics based on the location and factors of this difficulty. More researchers are willing to study and develop all the difficulties experienced by students and factors that influence students' difficulties or failures in the learning process and solving math problems and concrete efforts to overcome them.

\section{REFERENCES}

Andri, dkk. (2020). Analisis Kesulitan Belajar Matematika Kelas V Sd Negeri 25 Rajang Begantung. J-PiMat, 2(2), 231-241. DOI: https://doi.org/10.31932/j-pimat.v2i2.869

Abrar, A. I. P. (2018). Kesulitan Siswa SMP Belajar Konsep Dan Prinsip Dalam Matematika. AlKhwarizmi:Jurnal Pendidikan Matematika Dan Ilmu Pengetahuan Alam, 2(1), 59-68. 8. https://doi. org/10.24256/jpmipa.v2i1.102

Chotimah, N. H. (2014). Pengaruh Model Pembelajaran Generatif(MPG) Terhadap Kemampuan Pemecahan Masalah dan Disposisi Matematis Siswa di Kelas X pada SMA Negeri 8.

Skripsi.Universitas PGRI Palembang Palembang. Skripsi.Universitas PGRI Palembang.

Djumali dkk. (2014). Landasan Pendidikan. Gava Media.

Dwidarti, U., Mampouw, H. L., \& Setyadi, D. (2019). Analisis Kesulitan Siswa Dalam Menyelesaikan Soal Cerita Pada Materi Himpunan. Jurnal Cendekia : Jurnal Pendidikan Matematika, 3(2), 315322. https://doi.org/10.31004/cendekia.v3i2.110

Erwin Sulaiman, dkk. (2016). Upaya Peningkatan Kemampuan Pemecahan Masalah Matematika Siswa Melalui Strategi Problem Based Learning Pada Kelas VIII C SMP Muhammadiyah 29 Sawangan Depok. 37-38. Jurnal Pendidikan Matematika \& Matematika., 2(1). DOI: https://doi.org/10.24853/fbc.2.1.31-43

Fauzi, Irfan dan Andika, A. (2020). Analisis Kesulitan Belajar Siswa Pada Materi Geometri Di Sekolah Dasar. Jurnal Matematika Kreatif-Inovatif, 11(1), 28-35. DOI:10.15294/kreano.v11i1.20726

Hasan, B. (2015). Penggunaan Scaffolding Untuk Mengatasi Kesulitan Menyelesaikan Masalah Matematika. Apotema, 1(1), 88-89. DOI: https://doi.org/10.46244/numeracy.v7i1.998

Kereh, C. T., Sabadar, J., \& Tjiang, P. C. (2013). Kereh, C. T., Sabadar, J., \& Tjiang, P. C. (2013). Identifikasi kesulitan belajar mahasiswa dalam konten matematika pada materi pendahuluan fisika inti. In Proceedings of Seminar Nasional Sains dan Pendidikan Sains VIII, Fakultas Sains dan Matematika, (pp. 10-17). UKSW

Melisari, D. (2020). Analisis Kesalahan Siswa Dalam Menyelesaikan Soal Pemahaman Konsep Matematika Sekolah Dasar Pada Materi Bangun Datar. Jurnal Cendekia: Jurnal Pendidikan 
Matematika, 4(1), 172-182. DOI: https://doi.org/10.31004/cendekia.v4i1.182

Mufarizuddin. (2018). Analisis Kesulitan Pembelajaran Matematika Siswa Kelas V Sd Negeri 012 Bangkinang Kota. Journal on Education, 1(1), 40-47. . https://doi.org/10.31004/joe.v1i1.8

Mulyadi. (2010). Diagnosis Kesulitan Belajar Dan Bimbingan Terhadap Kesulitan Belajar Khusus. Nuha Litera.

Murzani. (2018). Analisis Kesulitan Belajar Siswa pada Mata Pelajaran Matematika di kelas IV SDN 9 Masbagik Utara Tahun Ajaran 2017/2018. Program Studi Pendidikan Sekolah Dasar, Fakultas Ilmu Pendidikan.

Nur, A. S., \& Palobo, M. (2018). Profil Kemampuan Pemecahan Masalah Matematika Siswa Ditinjau dari Perbedaan Gaya Kognitif dan Gender. Kreano, 9(2), 139-148. 8. https://doi.org/http://dx.doi. org/10.15294/kreano.v9i2.15067

Nurul Amallia dan Een Unaenah.(2018) Analisis Kesulitan Belajar Matematika pada Siswa Kelas III Sekolah Dasar. Attadib (Jurnal of Elementary Education. 2(2). DOI: https://doi.org/10.32507/attadib.v2i2.414

Rahayu Sri Waskitoningtyas. (2016). Anlisis Kesulitan Belajar Matematika Siswa Kelas V Sekolah Dasar Kota Balikpapan pada Materi Satuan Waktu Tahun Ajaran 2015/2016. Jurnal Ilmiah Pendidikan Matematika, 5 (1) DOI: http://doi.org/10.25273/jipm.v5i1.852

Safitri, S. R. E. dan A. S. (2020). Analisis Kesulitan Belajar Matematika pada Materi Bangun Ruang Kelas V SDN Banyuajuh 6 Tahun Ajaran 2019/2020. Prosiding Nasuonal Pendidikan, 1(1), 338-344.

Sholihah, S. Z., \& Afriansyah., E. A. (2017). Analisis Kesulitan Siswa dalam Proses Pemecahan Masalah Geometri Berdasarkan Tahapan Berfikir Van Hiele. Jurnal "Mosharafa," 6(2), 287298. DOI: https://doi.org/10.31980/mosharafa.v6i2.317

Sujana., W. C. (2019). Fungsi dan Tujuan Pendidikan. ADI WIDYA : Jurnal Pendidikan Dasar, 4(1), 29-39. DOI: http://dx.doi.org/10.25078/aw.v4i1.927

Unaenah, een dan M. S. S. (2019). Analisis Pemahaman Konsep Matematis Siswa Kelas 5 Sekolah Dasar Pada Materi Pecahan. Jurnal Basicedu, 3(1), 106-111

DOI: https://doi.org/10.31004/basicedu.v3i1.85.

Utari, Dian Rizky, M. Y. S. W. (2019). Analisis Kesulitan Belajar Matematika dalam Menyelesaikan Soal Cerita. Jurnal Ilmiah Sekolah Dasar, 3(4), 546-552. DOI: http://dx.doi.org/10.23887/jisd.v3i4.22311

Wiryanto. (2020). Proses Pembelajaran Matematika Di Sekolah Dasar Di Tengah Pandemo Covid19. Jurnal Review Pendidikan Dasar: Jurnal Kajian Pendidikan Dan Hasil Penelitian, 6(2). DOI: http://dx.doi.org/10.26740/jrpd.v6n2.p125-132

Widyasari, dkk. (2015). Analisis Kesulitan-Kesulitan Belajar Matematika Siswa Kelas IV Dalam Implementasi Kurikulum 2013 Di SD Piloting Se-Kabupaten Gianyar. E-Journal PGSD Universitas Pendidikan Ganesha, 3(1), 1-11. DOI: http://dx.doi.org/10.23887/ijpgsd.v3i1.5069

Yeo, K. K. J. (2009). Secondary 2 Students' Difficulties in Solving Non-Routine Problems. Research in mathematics Education in Singapore, p. 1-30. International Journal for Mathematics Teaching and Learning, 1-30. ERIC Number: EJ904874

Yusmin, E. (2016). Kesulitan Belajar Siswa pada pelajaran Matematika (Rangkuman Dengan Pendekatan Meta-Ethnography). Jurnal Visi Ilmu Pendidikan, 9(1), 2119-2136 DOI: http://dx.doi.org/10.26418/jvip.v9i1.24806 